\title{
The University and Its Regional Economic Context, Productive Mining Sector Demands on Education
}

\author{
Ana María Graffigna*, Carina Fraca \\ Faculty of Education, Catholic University of Cuyo, San Juan, Argentina \\ Email address: \\ agraffigna@uccuyo.edu.ar (A. M. Graffigna), carinafraca@gmail.com (C. Fraca)
}

\section{To cite this article:}

Ana María Graffigna, Carina Fraca. The University and Its Regional Economic Context, Productive Mining Sector Demands on Education. International Journal of Economic Behavior and Organization. Vol. 3, No. 5, 2015, pp. 74-77. doi: 10.11648/j.ijebo.20150305.12

\begin{abstract}
This presentation describes some conclusions taken from research carried out by a network of universities from the macro Andean region of San Juan-Coquimbo regarding the relationship between these universities and the productive sector. The objective of these actions is to contribute to the universities' strategic planning and to the definition of institutional policies promoting regional development. In this particular case, we address the demands of the productive mining sector on academic institutions. A methodological qualitative approach is used. The techniques and instruments used include: document analysis, interviews and focus groups to gather the opinions of academic experts on the matter, both references from the productive sector and from the political sector of the macro region. Our work identifies educational needs/vacancies related to the region's mining activity and proposes lines of research oriented towards articulation between mining activity and other social actors and sectors of regional production. In this sense, our work describes the characteristics of the development of productive mining in the macro region, as well as the educational proposals related to the needs of the mining sector, to research activities, and to the development and transferring to the medium.
\end{abstract}

Keywords: Educational Demands, Productive Sector, Regional Economy, Andean Region's Universities

\section{Introduction}

Economic development in the Andean region is determined by its natural resources; the characteristics of both its climate and its soil are factors that condition productive development and the lifestyle of its population. In Argentina, and more specifically in the province of San Juan, mining activity represents a productive force that has reactivated the economy of a province whose soil dedicated to agriculture makes up only approximately $1.5 \%$ (Allub, 2012) [1]. The mining exploitation policies implemented in Argentina are contemporary, however, in other Latin American nations, particularly in Chile, this economic activity has been growing consistently and currently represents $19.7 \%$ of the country's GDP (Patrón Trujillo, 2015) [2]. Of particular interest is the perspective this country has regarding policies on the exploitation of its nonrenewable resources, policies focusing on sustainable development and on the social and ethical responsibility higher level institutions have to develop the continent (Gómez Sabaíni et al., 2015) [3].

Following the passing of National Law 25.429 which regulates mining investments in Argentine territory and the subsequent expansion of mining ventures, universities in the Andean region have generated projects and proposals which aim to conduct research on, contribute to, and accompany regional economic development. Nevertheless, these actions are hardly systematized. In the words of the Argentine president Nestor Kirchner [4], with respect to mining, "it is of utmost importance that the growth of its productive riches and investment is transferred to other sectors and to the communities where these investments are made; and that the population sees mining as bringing progress, job opportunities, and improvements in the quality of life, and relates this activity to the economic development and growth of the region where these investments are taking place".

\section{Objectives}

The objectives guiding our work seek to (a) analyze and strengthen the relationship between regional economies and the University, (b) identify educational needs/vacancies related to mining activity in the region and (c) elaborate lines of research oriented towards articulation between mining activity and other social actors and sectors of regional production. 


\section{Problem Description}

One of the most important ways to promote development, common to all nations, is through mining. The American continent is home to a mineral richness that has attracted explorers, conquistadors, and adventurers in search of gold and other minerals which the native inhabitants already exploited using very primitive methods (Tarrago, 2014) [5]. Currently, economic development responds to increasing demands, driving a market with constantly fluctuating prices and competitive demand, with industry that requires high levels of specialization and constant renewal of knowledge (Maldonado \& Paredes, 2014) [6]. Mining as a source of progress and development requires the dedicated support of universities, engineers from various professions, high level technicians and professions who, in general, command knowledge that is not always directly related to mining exploitation (Carrillo, 2015) [7].

Sixty percent of export earnings in the Andean region of San Juan-Coquimbo come from the mining industry. The region is rich in these resources but has not been able to take complete advantage of the economic boom that results from mining to develop an industry that allows for sustainable economic growth. It must advance in the efficient exploitation of resources towards a more complex stage where greater articulation capabilities and the generation of more integral solutions responding to the demands of more organized social groups are required, as are market competencies and the capacity for innovation and competitiveness. Proactive regulation and institutional operations that foresee conflicts and/or problems and that articulate solutions between interested parties and projects must also be constructed.

In this context, references from the productive sectors recognize the need to seek out in universities the knowledge necessary to take advantage of mining as a strategic sector for regional development. In our current historic moment, knowledge and its systematic application are necessary conditions for development. For this reason, universities must involve themselves in the task of encouraging this development as actors conscious of their social responsibility, protecting the environment and promoting social and community wellbeing through the transfer of knowledge and its application.

\section{Characteristics of Productive Mining Development in the Macro Region}

The historical evolution of mining activity in the macro region and its relationship to regional economic development have influenced the establishment of mining legislation in accordance with the principles of the State, influenced by the economic and social policies dominant in each era, in order to best use resources for national development. The norms currently in force regulating mining production both in Chile and in Argentina determine the way in which mining projects implemented impact employment rates, GDP and regional economic development. From a comparative perspective, we may observe international development and the ways in which mining could operate as a catalyst for the diversification of regional economies (Jimenez, 2013) [8].

It is necessary to strengthen the articulation between educational offers and employment demands of individual companies (Llisterri, J. et al., 2014) [9]; activities carried out jointly are mainly of research nature (ex. exploratory studies, soil studies, and environmental and social impact studies, among others), however, the formation of human capital does not always cover the demands of the productive sector (specifically in the formation of technicians and qualified laborers). A disciplinary bias exists in that each educational program forms specialists in specific areas, with graduates having only scant competencies complementary to their formation (ex. ability to work in a team, discourse competencies, oratory, clarity and consistency in the elaboration of reports, strategic planning, etc.). In Argentina, the lack of connections between companies and educational institutions negatively impacts the relevance of some educational programs and limits the possibilities students have to carry out internships in said companies; in Chile, some universities maintain strong connections with the productive sector which allows them to work together in synergy.

\section{Educational Proposals Related to the Needs of the Mining Sector, to Research Activities and to the Development and Transferring to the Medium}

With respect to the academic activities related to the productive mining sector carried out in universities of the Andean region, to the way in which curricular proposals originate and how these are modified as a result of the demands of the regional productive sector, we observe that there exist historical and foundational academic careers, as is the case of the Mining Engineering program, that date back to the 19th century and in those years positioned these universities at the vanguard of economic development. Graduate educational proposals, on the other hand, are more recent creations and respond to the currents demands of the productive mining sector. As regards Mining Engineering programs, the University of La Serena has recently transformed its curriculum, basing its decision to do so on research carried out with national funds and jointly with other Chilean universities.

The School of Engineering at the University of La Serena, the National University of San Juan, San Juan's Mining Chamber, the School Economic Sciences and Business at the Catholic University of Cuyo and the provincial commission on Environmental Impact have developed projects and actions impacting both the implementation of mining and the reference communities, as well as perspectives for the future. Connections between mining projects and the community 
also exist, forming part of the social web. The energy challenges implicit in mining development provide evidence for the need to create alternative and innovative proposals, based on the development of alternative energies which universities should research (Muñoz Rivera, 2012) [10]. The need to encourage the formation of dynamic professionals in accordance with current demand and environmental impact policies and their implementation must also be highlighted.

\section{Perspectives}

\subsection{With Respect to Educational Proposals, It Is Necessary to}

- Implement informal educational projects together with the business sector oriented towards facilitating a company's induction process and promoting a culture of work in each community -work habits, criteria for regulating income and expenses, diversification of economic activity-, among others.

- Design or strengthen educational offers related to mining safety, energy issues, hydrological issues, the environment, community work, and organizational innovation, among others.

- Strengthen interdisciplinary collaboration, including the Humanities and Social Sciences.

- Link graduate programs to research, thesis topics should be integrated into institutional lines of research related to productive sector problems.

- Establish trans-Andean cooperation between universities, taking into account actions which are planned, systematized and sustained for mutual collaboration.

- Develop distance learning educational proposals to promote the education of populations from rural areas far from urban centers but close to the mining ventures.

- Revise and update the curriculum in function of the research carried out, make curricular activities compatible to promote teaching and student exchanges. Make advances on issues related to co-professorship or double professorship.

- Promote technical education and the education of qualified laborers, as this is the education the productive sector currently demands.

- Work cooperatively with other universities for professional and pre-professional education (for example, double professorships in both undergraduate and graduate programs). It means academic internships between universities, students, etc.

- Organize groups of graduates who would like to form part of commissions responsible for following up on curriculum matters to promote updating course lists according to the demands of the productive sector.

\subsection{With Respect to Research, It Is Necessary to}

- Create a binational business-university research center. Orient research applied to problems related to the regional economic context.

- Make priority research areas dynamic so that they can be adapted to the changing global and local contexts.

- Replace credits in research publications with patents. This requires investments that exceed university budgets, however, it is an opportunity to establish business-university connections. Modify university norms to strengthen both applied research and publications.

- Allow for research activity currently carried out ad-honorem or with little incentive to increase in value using resources generated by and benefitting the productive sector.

- Tend towards the development of applied research activities in order to produce greater impact on the productive sector and the community in general.

- Create inter-institutional and intersectorial mining research centers.

- Disseminate information regarding research efforts carried out by different schools and/or institutions.

\subsection{With Respect to Transferring/Linking}

- Facilitate joint action between human resources as currently, a great division exists between professionals working in the education system (universities) and those working in the productive mining sector. Two parallel subsystems exist which need to be brought closer together.

- Work with reference communities of mining ventures.

- Promote the transfer of technology through public-private funds, creating and strengthening Business-University alliances.

\subsection{With Respect to the Relationship Between the Productive Sector - University - State, the Following Actions Are Identified as Priorities}

- Systematize the isolated integration efforts between Business-University-State and generate protocols that facilitate the integration and validation of actions.

- Open calls to link university and business. Finance research using resources from the fiduciary funds.

- Work together with Graduate Centers or Centers for Former Students, particularly those who work in the mining area, to create action plans to provide current students with scholarships.

- Establish the figure of a broker or coordinator who would research university offers and productive sector demands and who would be an intermediary between the University and the mines.

- Hold regular meetings with university and business professionals to learn about demands and propose tangible educational offers.

- Together with the mining companies, conduct surveys to find out what management, operational and prospective problems must be solved (Universities + professional groups). 
- Create a binational agency of science and resource management to make public investment efficient.

- Strengthen alliances between companies so that the University becomes the base of professional support generating patentable innovation.

- Strengthen the trust universities place in companies, community organizations and public administration to evaluate ex-post projects.

- Develop periodic exchange experiences.

- Generate opportunities for taxation so that companies may deduct taxes for the promotion of applied research.

- Follow-up with graduates using a platform. This will allow for the planning of annual meetings to create working agreements among the companies where these graduates work with the objective of obtaining scholarships, memories, software, internships, professional practice experiences, and employment. This relationship would also allow the program to provide training, consulting and research.

One urgent task that will allow for articulation between the productive mining sector and universities to be carried out is to examine each of the areas considered to be strategic in great detail, evaluating what exists now and what objectives need to be met in the future. The presence of professors in the industry allows for the discovery both of problems to solve through investigation and weaknesses of the mining professionals educated at university. Joint work between Universities and the productive sector must be carried out within a framework of mutual benefit, where companies should contribute funds to the development of projects that seek to find solutions to problems of interest both for said companies and the university.

\section{Acknowledgements}

This presentation forms part of a broader research project entitled "Productive sector demands on formal education," and as such its findings and conclusions are provisional while the research project remains in effect.

\section{References}

[1] Allub, L. (2012). Impactos sociales de las tecnologías de riego en agroecosistemas áridos (San Juan, Argentina). Cuadernos de Desarrollo Rural, (26).

[2] Patrón Trujillo, P. A. (2015). Análisis de los efectos económicos y socio-políticos en Chile de la tradición exportadora minera y del TLC entre China y Chile, en especial para el período 2006-2012. Universidad del Rosario. Bogotá.

[3] Gómez Sabaíni, J. C., Jiménez, J. P., \& Morán, D. (2015). El impacto fiscal de la explotación de los recursos naturales no renovables en los países de América Latina y el Caribe.

[4] President Nestor Kirchner, in his presentation of the national mining plan. Buenos Aires. 2004.

[5] Tarrago, M. N. (2014). Pueblos originarios y la conquista: Nueva Historia Argentina (Vol. 1). Sudamericana.

[6] Maldonado, F. C., \& Paredes, L. F. T. (2014). Posibilidades de gobernabilidad y gobernanza en distintos tipos de minería. OPERA-Observatorio de Políticas, Ejecución y Resultados de la Administración Pública, (14).

[7] Carrillo, S. (2015). Minería en Sudamérica: intervención comunicativa para un desarrollo sostenible. Conexión, (3), 50-65. PUCP, Lima.

[8] Jiménez, E. M. (2013). La evolución de las políticas regionales en los países andinos: una visión comparativa. Documentos y Aportes, 1(21), 7-39. Universidad Nacional del Litoral. Entre Ríos.

[9] Llisterri, J. J., Gligo, N., Homs, O., \& Ruíz-Devesa, D. (2014). $\mathrm{N}^{\circ} 13$. Educación técnica y formación profesional en América Latina. El reto de la productividad. Serie Políticas Públicas y Transformación Productiva, 13, Caracas: CAF. Retrieved from http://scioteca.caf.com/handle/123456789/378.

[10] Muñoz Rivera, F. (2012). Enfrentando el desajuste entre la oferta del sistema educacional técnico y la demanda de capital humano en la industria minera. Retrieved from http://www.repositorio.uchile.cl/handle/2250/111976. 